\title{
Vertical variability of wild fish assemblages around sea-cage fish farms: implications for management
}

\author{
Tim Dempster ${ }^{1, *}$, Damian Fernandez-Jover ${ }^{2}$, Pablo Sanchez-Jerez ${ }^{2}$, \\ Fernando Tuya $^{3}$, Just Bayle-Sempere ${ }^{2}$, Arturo Boyra ${ }^{3}$, Ricardo J. Haroun ${ }^{3}$ \\ ${ }^{1}$ SINTEF Fisheries and Aquaculture, 7465 Trondheim, Norway \\ ${ }^{2}$ Unidad de Biologia Marina, Departamento de Ciencias del Mar y Biologia Aplicada, Universidad de Alicante, \\ Ap.C. 99, 03080 Alicante, Spain \\ ${ }^{3}$ BIOGES, Department of Biology, Faculty of Marine Sciences, University of Las Palmas de Gran Canaria, \\ 35017 Las Palmas, Spain
}

\begin{abstract}
Wild fish were counted in 4 depth-related strata (bottom, midwater, cage and surface) around 3 floating sea-cage fish farms (Altea, Campello, Guardamar) along the Spanish coastline and 2 farms (Los Cristianos, San Andrés) in the Canary Islands. Almost 200000 wild fish belonging to 53 species were seen; representatives of Sparidae (8 species), Carangidae (6 species), Mugilidae ( 5 species) and Chondrichthyid rays ( 7 species) were commonly observed. At all 5 farms, 1 to 3 taxa accounted for $>74 \%$ of the abundance and $>94 \%$ of the biomass of aggregated wild fish. Abundances (5.7 to 162 times) and biomasses (42 to 1728 times) of wild fish were higher in the cage stratum at the 3 Mediterranean farms than at the bottom. In contrast, abundances and biomasses of wild fish at the Canary Island farms were highest at the bottom at San Andrés and highest at the surface at Los Cristianos. Large differences in the sizes of associated fish existed among farms, with low percentages of fish $>20 \mathrm{~cm}$ total length at Guardamar, Los Cristianos and San Andrés (11 to $25 \%$ ) compared to Altea and Campello (81 to $95 \%$ ). However, the greatest proportions of large fish were present in the cage stratum at each of the 5 farms. This variability suggests that assemblage structure and aggregated biomass of wild fish at farms cannot be predicted prior to their installation, causing uncertainty in modelling of nutrient dispersal. Further, the sedimentation 'footprint' of temperate seacage fish farms may vary depending on (1) the species and biomass of associated wild fish, and (2) where these fish are distributed in the water column. As wild fish consume lost feed and assimilate nutrients, we suggest that coastal managers prohibit fishing of large planktivorous species at farms to fully harness their ability to ameliorate benthic impacts.
\end{abstract}

KEY WORDS: Aquaculture · Fish farm · Wild Fish · Impact · Assemblage • Management · Mediterranean Sea · Eastern Atlantic

Resale or republication not permitted without written consent of the publisher

\section{INTRODUCTION}

Coastal sea-cage fish farms are widespread throughout the world and produce almost 2.5 million tons of fish $\mathrm{yr}^{-1}$ (FAO 2003). In temperate and tropical warm water areas, a wide variety of species are cultured and significant sea-cage industries exist in China (>560000 $\mathrm{t} \mathrm{yr}^{-1}, \mathrm{FAO} 2003$; approx. 1 million cages of various sizes in coastal waters, Feng et al. 2004), Japan (>260000 $\mathrm{t} \mathrm{yr}^{-1}, \mathrm{FAO} 2003$ ) and in numerous countries throughout southeast Asia such as Indonesia, the Philippines and Australia. Throughout the Mediterranean Sea, both gilthead seabream Sparus aurata and European seabass Dicentrarchus labrax are cultured extensively. Combined production of these 2 species now exceeds $140000 \mathrm{t} \mathrm{yr}^{-1}$ (FAO 2003, Federation of European Aquaculture Producers, www.feap.info/feap) in hundreds of farms (Theodorou 1999, Sanchez-Mata \& Mora 2000). Rapid expansion of the industry throughout the Mediterranean continues as new farms 
are created and existing farms increase in size. In the Canary Islands, 19 farms existed in 2003 with a total production of $3700 \mathrm{t}$ (Asociación Empresarial de Productores de Cultivos Marinos, www.apromar.es).

While the general environmental effects of coastal sea-cage fish farms are well documented (e.g. Karakassis et al. 2000, Black 2001), the close association of wild fish with farms is poorly understood (Dempster \& Taquet 2004). Dempster et al. (2002) demonstrated that sea-cage fish farms act as 'super-FADs' (FAD: fish aggregation device) in the southwestern Mediterranean Sea, attracting large multi-species schools of pelagic fish. Large aggregations of pelagic and/or demersal fish have since been described around seacage fish farms in several temperate and tropical locations, including Greece (Smith et al. 2003, Thetmeyer et al. 2003), the Canary Islands (Boyra et al. 2004, Tuya et al. 2005), Australia (Dempster et al. 2004) and Indonesia (D. McKinnon pers. comm.). Due to the size of aggregations, fish farms in warm-water areas may affect a variety of ecological attributes of associated wild fish, including: diet, condition, parasite loads, susceptibility to fishing pressure, and presence, abundance and residence in a particular area (Bjordal \& Skar 1992, Dempster et al. 2002).

Food originating from fish farms is available in 2 forms to wild fish in the vicinity: as large food pellets lost through the cage, and as a 'soup' of particulate organic matter (POM) of broken pellets and faeces from caged fish. High abundances of wild fish may greatly influence the dynamics of nutrient flows via the consumption of food available around farms.

Two recent caging experiments that excluded fish from beneath farms showed that wild fish consumed a large proportion of the total sedimenting nutrients (80\%, Vita et al. 2004; 40 to $60 \%$, Felsing et al. 2005). The extent to which waste food pellets and POM derived from a farm are consumed will depend largely on the biomass of wild fish around cages, and the species composition of the assemblage. Wild fish may be important in both (1) assimilating a proportion of the nutrients lost through the cage, and (2) dispersing particles and nutrients that originate at farms to greater distances than current models predict, as has been suggested for fish farms in freshwater systems (Håkanson et al. 1998, Johansson et al. 1998). Whether aggregations are predominantly pelagic or demersal will also influence where in the water column unused feed and faeces from farmed fish are consumed, and the extent of sediment perturbation due to feeding activities. Mugil cephalus kept in experimental enclosures on the bottom reduced the impact of sea-cages by mixing, oxygenating and re-suspending sediments and enhancing effluent dispersal (Katz et al. 2002). If great differences exist in the types (pelagic or demersal) and biomasses of aggregated wild fishes among farms, their influence on farm nutrient and sediment settlement patterns on the seafloor may vary accordingly.

Previous studies on the assemblages of wild fish associated with farms have described broad differences among farms separated by spatial scales of $10 \mathrm{~s}$ to 100 s of kilometres, and by temporal scales of months to a year (Dempster et al. 2002, Boyra et al. 2004). However, no information on the spatial variability of wild fish within farms and with depth exists. Preliminary observations at farms suggested that abundance, biomass, assemblage composition, fish size and life history stage varied with both water depth and different areas within sea-cage complexes. Therefore, we aimed to quantify fish assemblages on vertical (among depth strata) and horizontal (among sites) spatial scales of 10 s of metres within fish farms during the morning feeding hours, when wild fish were most likely to consume lost feed. Further, we investigated similar fish farms in the southwest Mediterranean Sea and in the Canary Islands to determine if the observed patterns in fish assemblage structure were consistent among farms.

\section{MATERIALS AND METHODS}

Locations studied. We counted fish at 3 fish farms on the coast of Spain in the southwestern Mediterranean Sea, and at 2 fish farms located off Tenerife in the Canary Archipelago in the central east Atlantic (Fig. 1) during October and November 2004. All 5 farms cultured both gilthead seabream Sparus aurata and European seabass Dicentrarchus labrax. The number of cages (5 to 24$)$, cage diameter (17 to $25 \mathrm{~m}$ ) and net depth (13 to $17 \mathrm{~m})$ used at the farms varied, and total annual production at the farms ranged from 125 to $1000 \mathrm{t} \mathrm{yr}^{-1}$. Distance from the nearest coast varied from 0.4 to $3.7 \mathrm{~km}$, and water depths at which farms were located varied from 22.6 to $40 \mathrm{~m}$. Specific characteristics for each fish farm location are given in Table 1.

Measurements of physical variables. Temperature was measured in the 4 count strata (surface, cage, midwater and bottom) each day when counts were made, using a dive computer thermometer. To estimate visibilities and use as an index of turbidity, we made horizontal Secchi disc readings at each depth strata (surface, cage, midwater and bottom) on each sampling day. One diver held the Secchi disc while the other swam away with a tape measure to determine the Secchi distance.

Timed visual counts of fishes. Previous count techniques around farms have used either pelagic (Dempster et al. 2002) or benthic transects (Boyra et al. 2004, Tuya et al. 2005). Since visibilities were likely to vary 


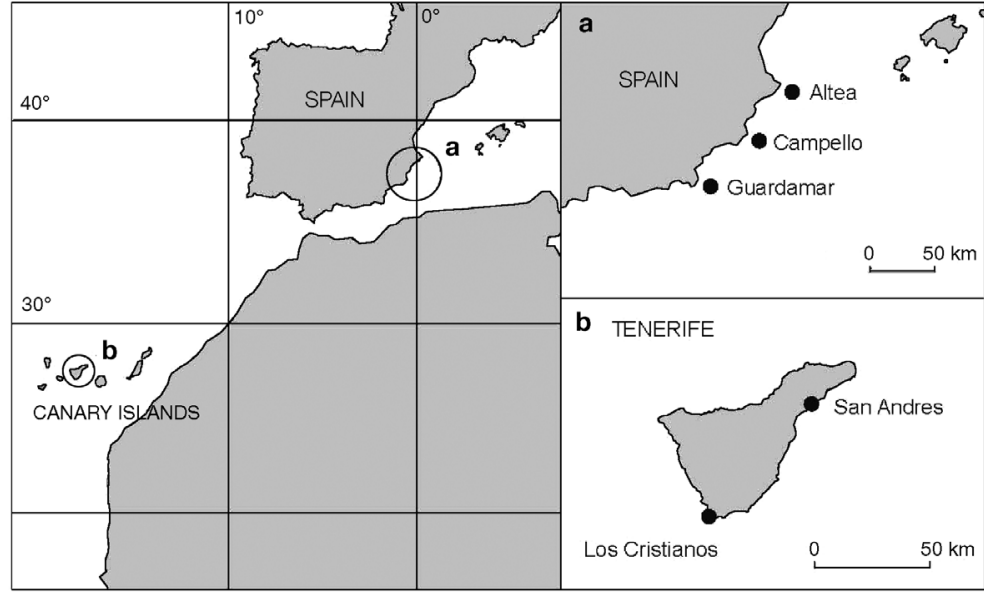

Fig. 1. Map of the 5 fish farms: (a) 3 in the Mediterranean Sea on the southeast coast of Spain (Altea, Campello, Guardamar), (b) 2 in the Canary Islands (Los Cristianos, San Andrés)

between the different depth strata, and performing transects of defined lengths in midwater is difficult, we designed a technique that would be robust for comparisons of counts at a range of depths and visibilities. We used stationary $1 \mathrm{~min}$ timed counts with the diver slowly revolving through $360^{\circ}$. Fish were counted $1 \mathrm{~m}$ above and below eye-level out to a radius of $5 \mathrm{~m}$. Bottom counts included the water column to $2 \mathrm{~m}$ above the substrate. Cylindrical count volumes were approximately $157 \mathrm{~m}^{3}$; all counts were subsequently standardized to $150 \mathrm{~m}^{3}$. Preliminary work to develop the technique indicated that stationary counts of longer duration were impractical, particularly when large mobile schools of fish were present. The restricted radius of $5 \mathrm{~m}$ from the diver ensured that counts were not influenced by varying visibilities at different depths or at different times. This may have excluded some large predatory species which we knew to be 'diver-negative' from previous work, such as Lichia amia, Thunnus thynnus and Coryphaena hippurus; however, these species are relatively rare in counts within fish farm complexes (Dempster et al. 2002). Most species associating with farms are 'diver-positive' or 'diverneutral', including the 10 most abundant species of wild fish that associated with both the Mediterranean and Canary Island farms (Dempster et al. 2002, Boyra et al. 2004). As such, these species were adequately sampled by the count technique. Further, we were confident that bottom counts were representative of demersal species and that diver-negative fish were not abundant beyond the $5 \mathrm{~m}$ count radius. Observations on days when visibili- ties were exceptionally good on the bottom $(>15 \mathrm{~m}$ ) indicated that the same species were present both within and beyond a $5 \mathrm{~m}$ radius of the diver.

Counts were made using a modification of the technique of Harmelin-Vivien et al. (1985). Individuals were counted for schools of up to 10 fish, with 5 abundance classes (11-30, 31-50, 51-100, 101-200, 201-500) used when larger schools of fish were present. In each timed count, the abundance of each fish species was recorded. As we could not always separate Mugil cephalus, Liza aurata, L. saliens, L. ramala and Chelon labrosus during counts, we pooled these as Mugilidae. Total lengths (TLs) of fish were estimated in intervals of $2 \mathrm{~cm}$. For Chondricthyid rays, body widths (BW) were estimated. Lengths of groups of fish were first estimated by assigning each fish to the mid-point of its observed size range (Dempster et al. 2002, Miller \& Gerstner 2002). Estimated fish sizes of the most abundant taxa at Mediterranean farms were calibrated with fish of known size caught by spearfishing at each of the 3 farms on days when sampling occurred (Mugilidae: $50.9 \mathrm{~cm} \pm 2.0, \mathrm{n}=19$; Trachinotus ovatus: $31.5 \pm 0.6$, $\mathrm{n}=15$; Trachurus mediterraneus: $34.9 \pm 1.3, \mathrm{n}=12$ [mean $\pm \mathrm{SE}]$ ). Biomass estimates for all species were made in EcoCEN (Bayle et al. 2002). For the 3 abovementioned taxa, length-weight relationships derived from specimens spearfished in the immediate vicinity of fish farms were used. For all other species, published length-weight relationships were taken from FishBase (Froese \& Pauly 2000). Abundance and biomass estimates derived from the visual counts provided a useful index for comparison among farms and depths, and any measurement error should have been consistent among farms, depths, sampling times and

Table 1. Physical and environmental characteristics of 5 sea-cage fish farms for cultivation of Sparus aurata and Dicentrarchus labrax. Production values are for 2004

\begin{tabular}{|lcccccc|}
\hline & $\begin{array}{c}\text { Distance } \\
\text { offshore } \\
(\mathrm{km})\end{array}$ & $\begin{array}{c}\text { Water } \\
\text { depth } \\
(\mathrm{m})\end{array}$ & $\begin{array}{c}\text { No. of } \\
\text { cages }\end{array}$ & $\begin{array}{c}\text { Cage } \\
\text { diameter } \\
(\mathrm{m})\end{array}$ & $\begin{array}{c}\text { Cage } \\
\text { depth } \\
(\mathrm{m})\end{array}$ & $\begin{array}{c}\text { Production } \\
\text { in 2004 } \\
\left(\mathrm{t} \mathrm{yr}^{-1}\right)\end{array}$ \\
\hline $\begin{array}{l}\text { Mediterranean } \\
\quad \text { Altea }\end{array}$ & 2.8 & 34.0 & 10 & 25 & 16 & 442 \\
$\quad$ Campello & 3.2 & 28.6 & 12 & 17 & 17 & 300 \\
Guardamar & 3.7 & 22.6 & 24 & 19 & 15 & 1000 \\
Canary Islands & & & & & & \\
$\quad \begin{array}{l}\text { Los Cristianos } \\
\text { San Andrés }\end{array}$ & 0.4 & 40.0 & 6 & 17 & 13 & 125 \\
\hline
\end{tabular}


sites. The count method was not designed to estimate the overall abundance and biomass aggregated at each farm as count volumes could not be precisely standardised.

Experimental design. At each farm, fish were counted 3 times (3 separate days) over a period of 2 mo. Farms were divided to give 2 separate sites, approximately 50 to $100 \mathrm{~m}$ apart. At each of the 2 sites, $8 \times$ 1 min counts were made in each of 4 distinct depth strata: bottom, midwater between the cage and the bottom (hereafter called 'midwater'), water surrounding the cage (hereafter called 'cage') and the surface. As bottom depths varied among farms, depths of bottom counts varied accordingly (Table 1). Surface counts were made in 0 to $2 \mathrm{~m}$ of water, cage counts at 8 to $12 \mathrm{~m}$, midwater counts at 18 to $24 \mathrm{~m}$ and bottom counts at 22.6 to $40 \mathrm{~m}$. In total, $960 \times 1 \mathrm{~min}$ timed counts were made.

Species and size classes for multivariate and univariate analyses. Most of the species observed fell within a narrow size range. However, Mugilidae and Trachurus sp. were clearly represented by 2 distinct size cohorts of juvenile and large fish. Therefore, we separated Mugilidae $(<20 \mathrm{~cm}, \geq 20 \mathrm{~cm})$ and Trachurus sp. $(<20 \mathrm{~cm}$, $\geq 20 \mathrm{~cm}$ ) into 2 size classes before undertaking the multivariate and univariate analyses. For analysis of abundance and biomass, we also combined the 7 species of Chondrichthyid rays observed into one group.

Multivariate statistical analyses. Non-parametric multivariate techniques were used to compare assemblages among depths, farms and sampling times within farms. All multivariate analyses were performed using the PRIMER statistical package. Prior to calculating the similarity matrices, the data were pooled by summing the $16 \times 1 \mathrm{~min}$ counts at each depth ( 2 sites pooled) for each time, to reduce the stress of non-metric multidimensional scaling (nMDS) representation. Data were then 4 th root transformed to weight the contributions of common and rare species in the similarity coefficient (Clarke 1993). Triangular similarity matrices were calculated using the BrayCurtis similarity coefficient (Clarke \& Warwick 1994). Non-metric MDS (nMDS) was used as the ordination method. The analysis of similarity (ANOSIM) permutation test was used to assess the significance of differences among distinct assemblage groups (Clarke \& Green 1988, Clarke 1993). Taxa that had more influence on similarities within groups and dissimilarities among groups of assemblages were calculated using the similarity percentages (SIMPER) procedure (Clarke 1993).

Univariate statistical analyses. To test whether total abundances and biomasses of aggregated wild fishes varied among the 5 farms and 4 depths, we used ANOVA that incorporated the factors Depth (fixed), Farm (random), and a Depth $\times$ Farm interaction term.
As the dominant species that occurred at each of the farms were very different, we tested whether their abundances and biomasses varied among depths, sampling times and sites at each farm using an ANOVA with the terms Depth (fixed), Time (random), a Depth $\times$ Time interaction term and Site (random) nested within Depth $\times$ Time.

Prior to ANOVA, data were $\ln (x+1)$ transformed. Heterogeneity of variance was tested with Cochran's $C$-test. Because fish-count data contain many zeros, they are often non-normal and cannot be effectively transformed (Kingsford \& Battershill 1998, Hawkins \& Roberts 2004). Transformation did not produce homogeneous variances for abundances and biomasses of some individual taxa, so the significance level for ANOVA was set at the 0.01 level instead of 0.05 in these instances. Moreover, ANOVA is robust to heterogeneity of variances, particularly when experiments are large and balanced (Underwood 1997) as in this study.

\section{RESULTS}

\section{Visibilities and water temperatures}

Visibility varied among the 4 depth strata sampled at the 3 Mediterranean farms, with the bottom stratum generally having lower horizontal visibility than the

Table 2. Water temperature and visibility in each of the 4 depth strata at 5 sea-cage fish farms over the 3 sampling times. V: horizontal visibility estimated by Secchi disc

\begin{tabular}{|lcrc|}
\hline & Stratum & $\mathrm{V}(\mathrm{m})$ & Temp. $\left({ }^{\circ} \mathrm{C}\right)$ \\
\hline Mediterranean & & & \\
Altea & Surface & $19-25$ & $19-22$ \\
& Cage & $18-25$ & $19-22$ \\
& Midwater & $15-20$ & $19-22$ \\
Campello & Bottom & $6-15$ & $19-21$ \\
& Surface & $16-30$ & 21 \\
& Cage & $20-25$ & 21 \\
& Midwater & $12-18$ & $18.5-20$ \\
Guardamar & Bottom & $8-12$ & $16.5-20$ \\
& Surface & $12-20$ & $21-22$ \\
& Cage & $12-20$ & $21-22$ \\
Canary Islands & Midwater & $6-10$ & 20 \\
Los Cristianos & Bottom & $4-13$ & $19-21$ \\
& & & \\
& Surface & $20-25$ & 22 \\
& Cage & $20-25$ & 22 \\
San Andrés & Midwater & $20-25$ & 22 \\
& Bottom & $20-25$ & $22-23$ \\
& Surface & $21-24$ & $21-21.5$ \\
& Cage & $21-24$ & $21-21.5$ \\
& Midwater & $22-24$ & 21 \\
& Bottom & $22-24$ & $21-22$ \\
\hline
\end{tabular}


midwater, cage and surface strata (Table 2). In contrast, visibility did not vary with depth at the 2 Canary Island farms, ranging from 20 to $25 \mathrm{~m}$ throughout the water column. Lowest visibility was recorded on the bottom at Guardamar and ranged from 4 to $13 \mathrm{~m}$; the $4 \mathrm{~m}$ visibility occurred only on 1 sampling day. Water temperatures varied among the 4 depth strata and between days at the 3 Mediterranean farms. Water temperatures ranged from 16.5 to $22^{\circ} \mathrm{C}$ and were typically 1 to $2^{\circ} \mathrm{C}$ higher in the surface and cage strata than the bottom. The greatest differences between depth strata were observed on the second sampling day at Campello, with $21^{\circ} \mathrm{C}$ recorded at the surface and cage strata, $18.5^{\circ} \mathrm{C}$ in midwater and $16.5^{\circ} \mathrm{C}$ at the bottom. In contrast, temperatures at the Canary Island farms varied little throughout the water column at all 3 sampling times, ranging from 21 to $23^{\circ} \mathrm{C}$.

\section{Composition of wild fish species around sea-cage fish farms}

Twenty-six species were seen at the Mediterranean farms and 32 species were observed at the Canary Island farms (Appendix 1; www.int-res.com/articles/ suppl/m304p015_app.pdf). The most common families were Sparidae (8 species) and Carangidae (6 species), with Chondrichthyid rays also common (7 species). Only 3 species (Boops boops, Pagellus acarne and Synodus saurus) occurred at both the Mediterranean and Canary Island farms. Notably, a more species-rich assemblage existed on the bottom underneath the Canary Islands farms (27 species observed at 2 farms) compared to the Mediterranean (15 species at 3 farms), due partially to the diverse group of Chondrichthyid rays which were observed only at the Canary Islands.
Twenty-nine species were seen only in bottom counts and 7 species were seen only at the surface (Appendix 1). Sixteen species were observed in more than 1 depth stratum, with 7 species (Boops boops, Mugilidae, Pseudocaranx dentex, Pomatomus saltatrix, Trachinotus ovatus, Trachurus mediterraneus, Trachurus sp. $<20 \mathrm{~cm}$ ) seen at all depths. While assemblages at all farms were numerically dominated by planktivorous or food-pellet feeding species (e.g. Sardinella aurita, B. boops, T. mediterraneus, Mugilidae, T. ovatus), a number of large piscivores were also seen in counts (Pomatomus saltatrix, Sphyraena sphyraena, Sphyraena viridensis, Coryphaena hippurus, Auxis rochei, Sarda sarda). In addition to the ichthyofauna observed, bottlenose dolphins Tursiops truncatus occurred at both Canary Island farms. Dolphins were seen at Los Cristianos at sampling times 1 ( $\mathrm{n}=1$, TL = $220 \mathrm{~cm}$ ) and $2(\mathrm{n}=2, \mathrm{TL}=200$ to $220 \mathrm{~cm})$ and at San Andrés at sampling time $1(\mathrm{n}=8, \mathrm{TL}=200$ to $220 \mathrm{~cm})$.

\section{Variability of wild fish assemblages among farms and depth strata}

The 2-dimensional nMDS plot for the Mediterranean farms based on abundances and species enclosed 2 distinct groups which included: (1) all bottom assemblages at the 3 farms and 3 sampling times (44\% similarity), and (2) all surface assemblages at Guardamar and Campello but not Altea (52\% similarity, Fig. 2a). SIMPER analysis indicated that Serranus hepatus (64\%) and Gobius bucchichi (33\%) were responsible for over $90 \%$ of the similarity between the bottom samples at the 3 farms. Similarities within the surface assemblage group were largely due to similar abundances of Mugilidae <20 cm (75\%). ANOSIM indi- (a)

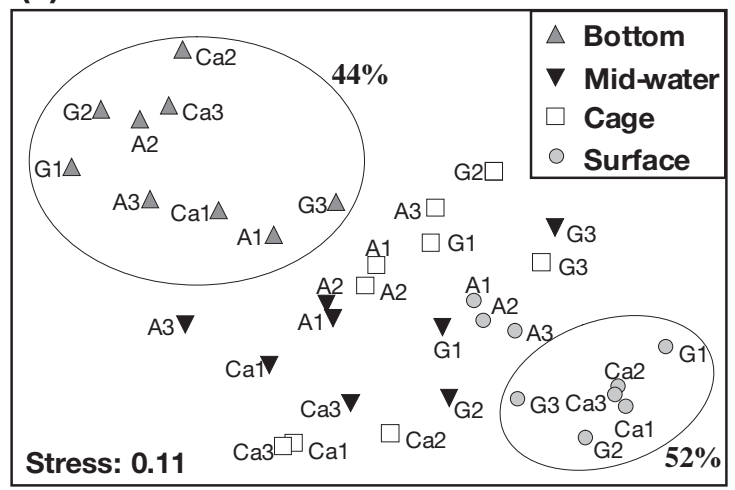

(b)

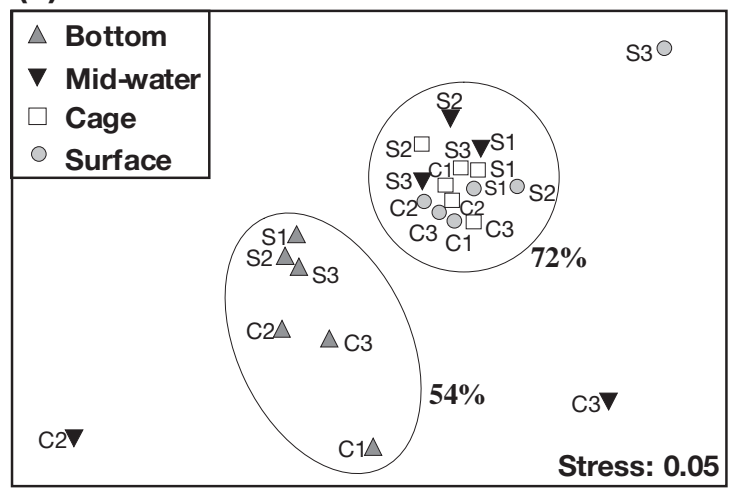

Fig. 2. Non-metric multi-dimensional scaling plots of wild fish communities at (a) 3 Mediterranean fish farms (A: Altea, Ca: Campello, G: Guardamar), and (b) 2 Canary Island fish farms (C: Los Cristianos, S: San Andrés). Circles with percentages (BrayCurtis similarities) enclose major assemblage groups with similarities greater than the given percentage. Numbers 1 to 3 refer to the 3 sampling times 
cated that these 2 distinct assemblage groups differed significantly from each other and all other assemblages identified in the midwater, cage and surface counts $\left(R_{\text {global }}=0.91, p<0.001\right)$. Between these bottom and surface assemblage groups, a broad intermediate array of assemblages existed which varied considerably among the midwater and cage strata at all 3 farms and sampling times and at the surface at Altea.

Assemblages at the 2 Canary Island farms were clearly differentiated into 2 distinct groups which included: (1) bottom assemblages observed at both farms at all 3 sampling times (54\% similarity), and (2) most of the assemblages observed throughout the rest of the 'water column' at all 3 sampling times ( $72 \%$ similarity, Fig. 2b). ANOSIM indicated that these 2 groups differed significantly $\left(\mathrm{R}_{\text {global }}=0.78, \mathrm{p}<0.001\right)$. SIMPER analysis indicated that Boops boops $(25 \%)$, Heteroconger longissimus $(12.3 \%)$, Bothus podus $(9.5 \%)$ and Spondyliosoma cantharus (8.5\%) were primarily responsible for similarities between assemblages in the bottom group, while similar abundances of $B$. boops $(86 \%)$ and Pseudocaranx dentex $(7.5 \%)$ contributed most to similarities in the water column group.

\section{Differences in total abundance and biomass among farms and depth strata}

Significant differences existed among depths and farms for total abundance and total biomass, with a highly significant Depth $\times$ Farm interaction for both factors (Table 3). Similar patterns of abundance with

Table 3. ANOVA comparing total abundances and biomasses of wild fish in the 4 depth strata among 5 sea-cage fish farms. Significant at ${ }^{* *} p=0.01,{ }^{* * *} p=0.001$. ns: not significant, B: bottom, M: midwater, C: cage, S: surface

\begin{tabular}{|c|c|c|c|c|c|}
\hline \multirow[t]{2}{*}{ Source } & \multirow[t]{2}{*}{ df } & \multicolumn{2}{|c|}{ Total abundance } & \multicolumn{2}{|c|}{ Total biomass } \\
\hline & & MS & $F$ & MS & $F$ \\
\hline Depth & 3 & 56.3 & $2.6^{* *}$ & 34.6 & $2.6^{* *}$ \\
\hline Farm & 4 & 27.5 & $36.8^{* * *}$ & 7.1 & $22.9^{* * *}$ \\
\hline Depth $\times$ Farm & 12 & 22.0 & $29.4^{* * *}$ & 13.2 & $42.8^{* * *}$ \\
\hline Residual & 40 & \multicolumn{2}{|l|}{0.8} & \multirow{2}{*}{\multicolumn{2}{|c|}{$\ln (x+1)$}} \\
\hline \multicolumn{2}{|c|}{ Transformation } & \multirow{2}{*}{\multicolumn{2}{|c|}{$\begin{array}{l}\operatorname{In}(X+1) \\
0.28 \mathrm{~ns}\end{array}$}} & & \\
\hline \multicolumn{2}{|l|}{ Cochran's $C$-test } & & & \multicolumn{2}{|c|}{$0.27 \mathrm{~ns}$} \\
\hline \multicolumn{6}{|c|}{ Post-hoc SNK tests for Depth $\times$ Farm interaction } \\
\hline \multicolumn{2}{|l|}{ Altea } & \multicolumn{2}{|c|}{$\mathrm{C}>\mathrm{S}>\mathrm{M}>\mathrm{B}$} & \multicolumn{2}{|c|}{$\mathrm{C}>\mathrm{S}>\mathrm{M}>\mathrm{B}$} \\
\hline \multicolumn{2}{|l|}{ Campello } & \multicolumn{2}{|c|}{$\mathrm{C}>\mathrm{S}>\mathrm{M}=\mathrm{B}$} & \multicolumn{2}{|c|}{$\mathrm{C}>\mathrm{M}>\mathrm{S}=\mathrm{B}$} \\
\hline \multicolumn{2}{|l|}{ Guardamar } & \multicolumn{2}{|c|}{$\mathrm{C}>\mathrm{S}>\mathrm{M}>\mathrm{B}$} & \multicolumn{2}{|c|}{$\mathrm{C}>\mathrm{M}>\mathrm{S}=\mathrm{B}$} \\
\hline \multicolumn{2}{|l|}{ Los Cristianos } & \multicolumn{2}{|c|}{$\mathrm{S}>\mathrm{C}>\mathrm{B}>\mathrm{M}$} & \multicolumn{2}{|c|}{$\mathrm{C}=\mathrm{S}>\mathrm{B}>\mathrm{M}$} \\
\hline \multicolumn{2}{|l|}{ San Andrés } & \multicolumn{2}{|c|}{$\mathrm{B}>\mathrm{M}>\mathrm{C}>\mathrm{S}$} & \multicolumn{2}{|c|}{$\mathrm{B}>\mathrm{C}=\mathrm{M}>\mathrm{S}$} \\
\hline
\end{tabular}

depth occurred at the 3 Mediterranean farms (Fig. 3), with Student-Newman-Keuls (SNK) tests indicating that abundances around the cages were significantly greater (1.5 to 5.6 times) than in the surface waters. SNK tests further separated the surface from both the midwater and bottom strata at all 3 farms. Across the 3 farms, fish were 5.7 to 162 times more abundant in the cage stratum than at the bottom. Patterns of total abundance differed between the 2 Canary Island farms. At Los Cristianos, highest abundances occurred sequentially in the surface, cage, bottom, then midwater strata. The surface and cage strata had between 8.5 and 17 times more fish than the bottom. In contrast to all other farms, total abundance in the bottom strata at San Andrés was 2 times higher than the abundance observed in midwater, and 2.5 to 3.4 times higher than those observed in the cage and surface strata.

At the 3 Mediterranean farms, total biomasses were significantly greater in the cage stratum than in any of the other depth strata (Table 3, Fig. 3). While a substantial biomass of wild fish was also observed at the surface at Altea, none of the other sampled depth strata contributed greatly to the aggregated biomass of wild fish. The greatest differences (42 to 1728 times) were observed between the cage and bottom strata at all 3 farms. At Los Cristianos, biomasses observed in
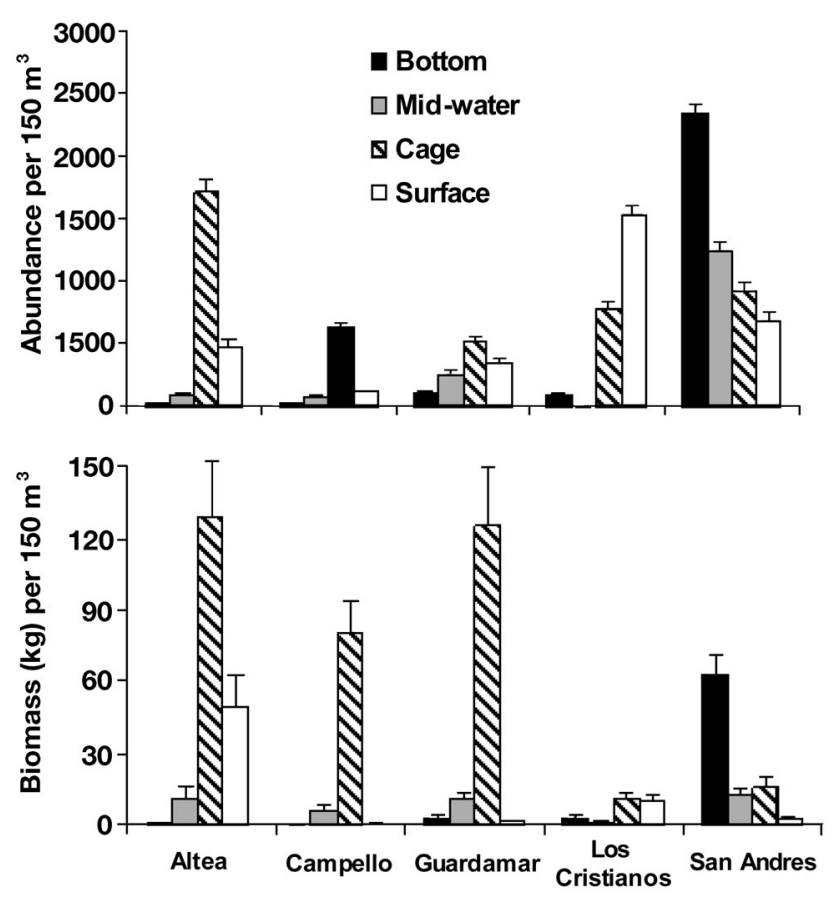

Fig. 3. Total abundance and biomass per $150 \mathrm{~m}^{3}$ for the 4 depth strata at each of the 5 fish farms. Bars are mean + SE of $48 \times 1$ min counts 
the 4 depth strata were quite low due to the small size of wild fish (predominantly Boops boops) that dominated the assemblage. However, total biomasses were clearly greater (3.5 to 4 times) in the cage and surface strata than at the bottom. San Andrés exhibited a markedly different pattern to all other farms; biomass was 4 times greater at the bottom than in the midwater and cage counts, with little aggregated biomass at the surface.

\section{Differences in the dominant species among farms and depth strata}

At all 5 farms, just 3 taxa accounted for $>74 \%$ of the total abundance and $>94 \%$ of the total biomass of aggregated wild fish. However, the abundance and biomass of these taxa varied greatly among the
5 farms (Figs. 4 \& 5). At Altea, Sardinella aurita (TL $=22$ to $32 \mathrm{~cm}$ ) dominated the assemblage in terms of both abundance (Fig. 4a) and biomass (Fig. 5a). Significantly greater abundances and biomasses of these fish occurred in the cage stratum than in all other depth strata; however, a significant interaction term at the lowest level of the ANOVA indicated that this varied with site within the farm and sampling time (Table 4a). Trachinotus ovatus abundances varied significantly at particular depths, sampling times and sites although biomasses did not vary significantly (Figs. 4b \& 5c). Mugilidae $<20 \mathrm{~cm}$ were abundant and occurred exclusively at the surface (Fig. 4c); however, they contributed little to the biomass at Altea. After $S$. aurita, Mugilidae $\geq 20 \mathrm{~cm}$ (Fig. 5b) was the next most important contributor to biomass, which was significantly higher at the surface than at all other depths.
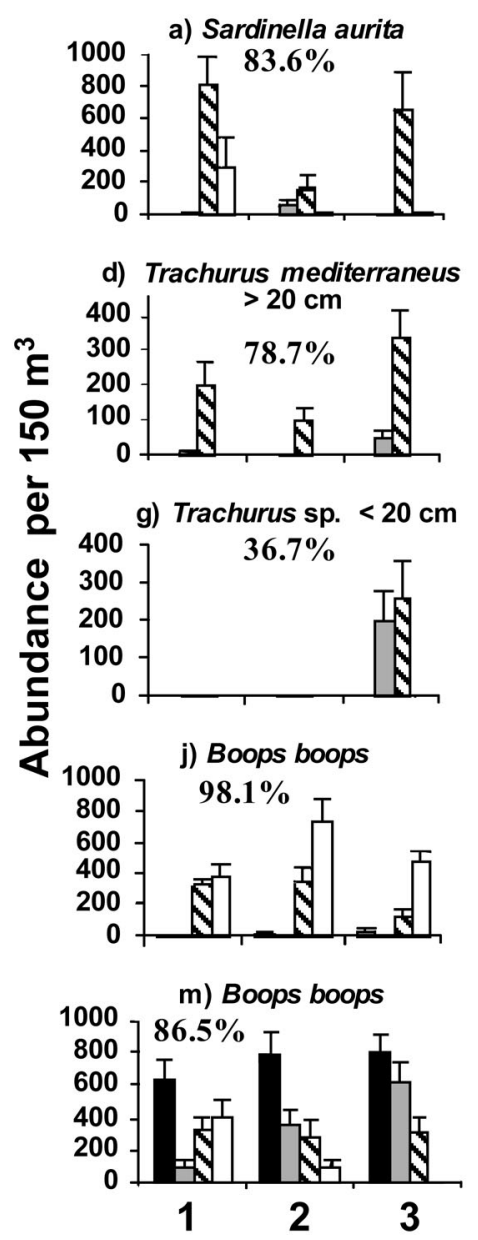

b) Trachinotus ovatus

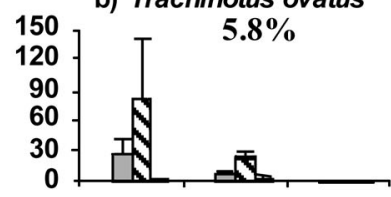

e) Mugilidae $<20 \mathrm{~cm}$

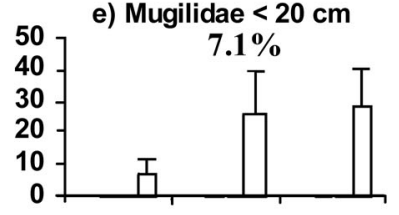

h) Mugilidae $>20 \mathrm{~cm}$
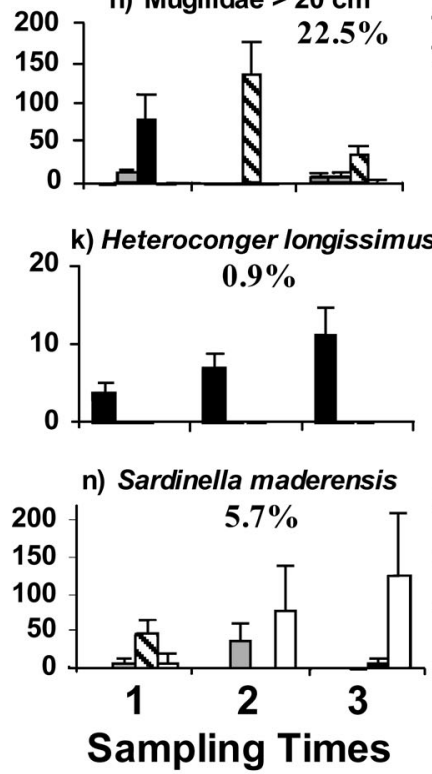

c) Mugilidae $<20 \mathrm{~cm}$

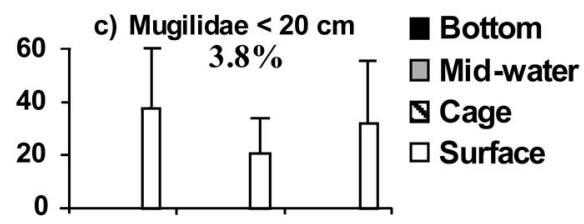

f) Oblada melanura
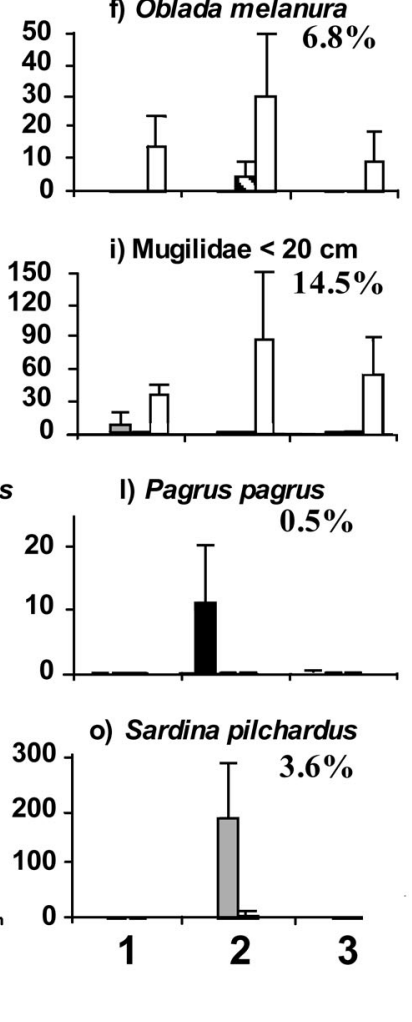

Fig. 4. Abundance per $150 \mathrm{~m}^{3}$ by depth strata at each of the 3 sampling times for the 3 most numerically dominant species at the 5 fish farms. Bars are mean + SE of $16 \times 1$ min counts. (a-c) Altea; $(d-f)$ Campello; $(g-i)$ Guardamar; (j-l) Los Cristianos; (m-o) San Andrés. The percentage given in each panel shows the contribution of that taxon to the overall abundance at the farm 
Abundance and biomass at Campello was heavily dominated by Trachurus mediterraneus ( $\mathrm{TL}=28$ to $40 \mathrm{~cm}$, Figs. 4d \& 5d), with both parameters significantly higher in the cage stratum than at all other depths (Table 4b). At Altea, Mugilidae $<20 \mathrm{~cm}$ occurred only in the surface waters (Fig. 4e) and contributed little to the biomass. Oblada melanura were significantly more abundant in surface waters (Fig. 4f), with highest biomasses recorded in surface waters at sampling time 2 (Fig. 5f). Sphyraena sphyraena were an important component of the biomass due to the appearance of hundreds of individuals in the cage stratum at the first sampling time (Fig. 5e).

At Guardamar, while Trachurus sp. $<20 \mathrm{~cm}$ were the most abundant species (Fig. 4g) due to their appear- ance in large numbers in the midwater and cage strata at sampling time 3, they contributed relatively little to the biomass (Fig. 5h). Instead, Mugilidae (TL $=22$ to $>60 \mathrm{~cm}$ ), which were always significantly more abundant in the cage stratum (Table $4 \mathrm{c}$, Fig. 4h), accounted for $97.8 \%$ of the accumulated biomass of wild fish (Fig. 5g). Small mugilids $<20 \mathrm{~cm}$ were also abundant, significantly more so in the surface waters than at all other depths (Fig. 4i). Trachurus mediterraneus were the third greatest component of the biomass at Guardamar, with significantly higher biomasses recorded in the midwater at sampling time 1 than at all other depth and sampling time combinations (Fig. 5i).

Ninety-eight percent of the abundance and $91 \%$ of the biomass of wild fish at Los Cristianos was due to
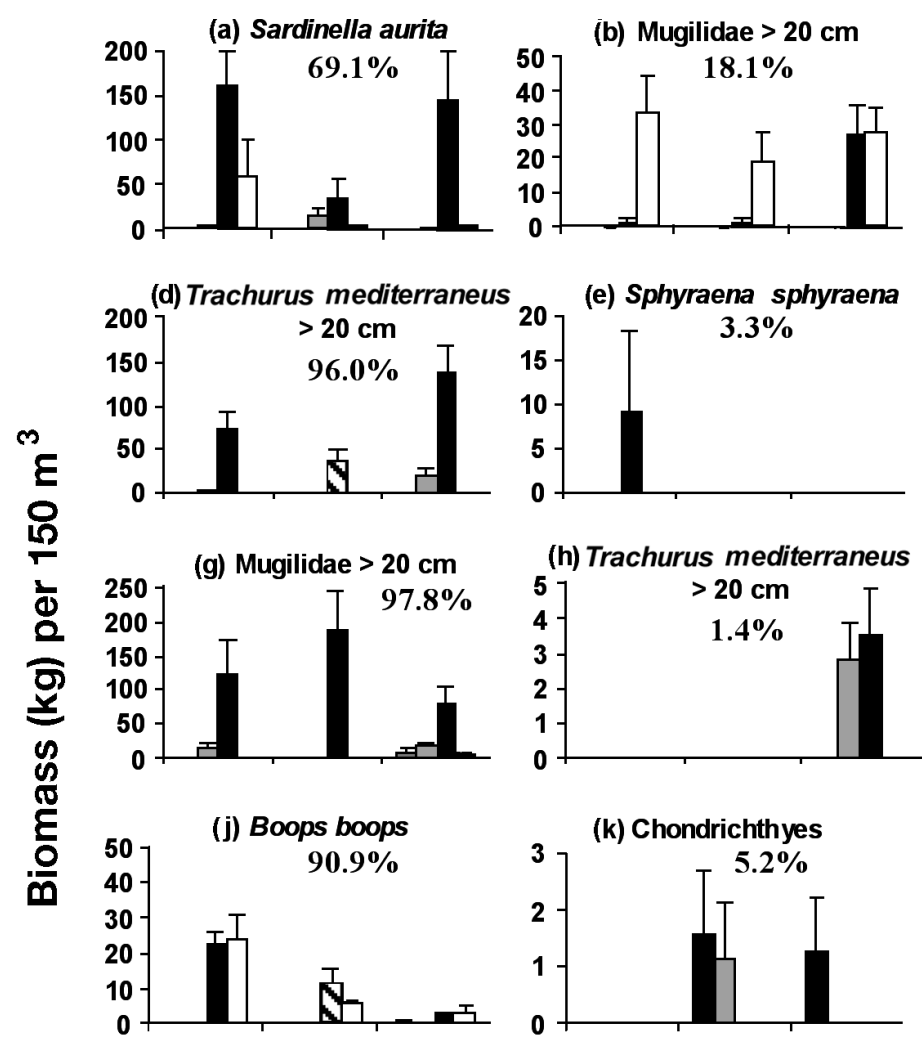

(h) Trachurus mediterraneus
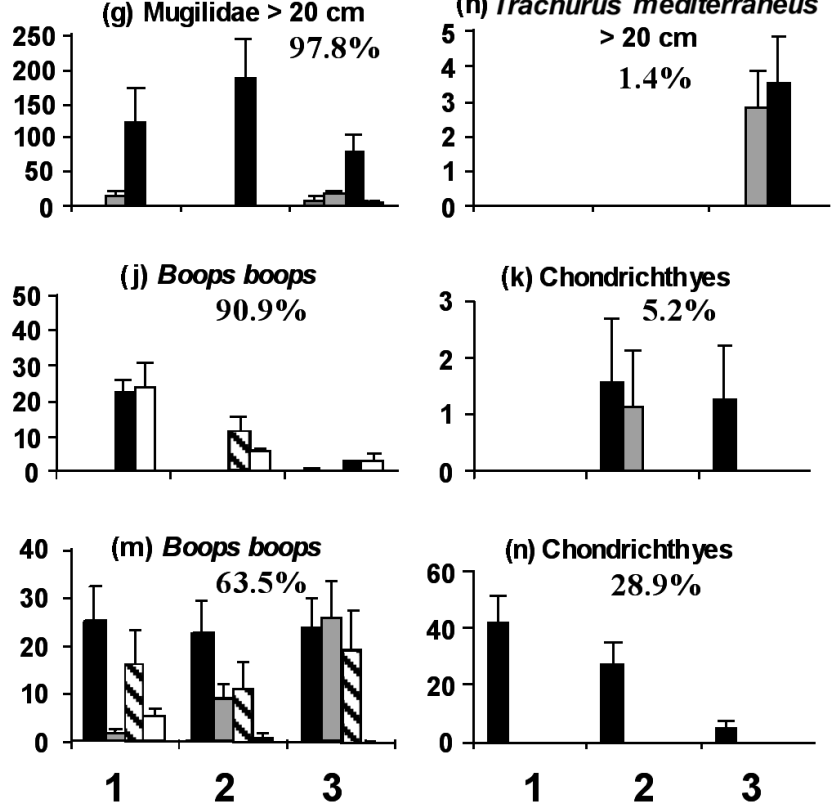

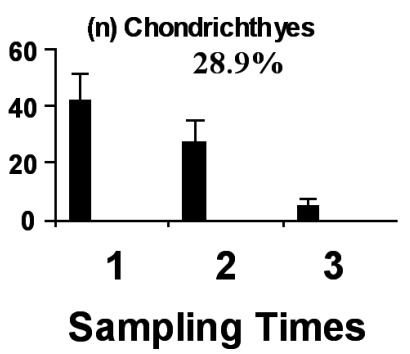

(c) Trachinotus ovatus

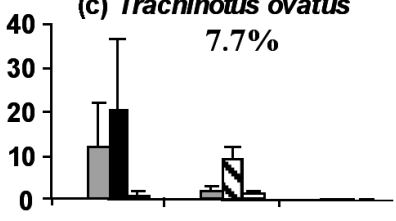

Bottom $\square$ Mid-water

$\triangle$ Cage $\square$ Surface
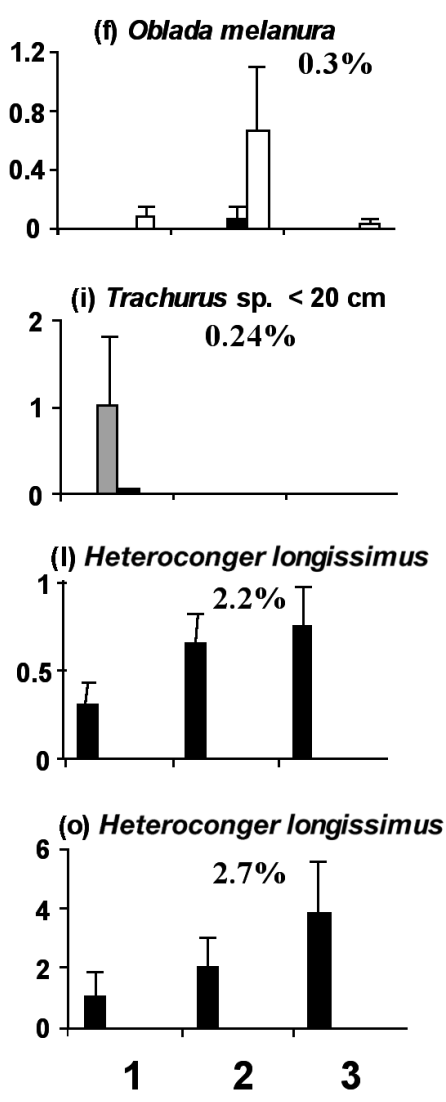

Fig. 5. Biomass per $150 \mathrm{~m}^{3}$ by depth strata at each of the 3 sampling times for the 3 species contributing most biomass at the 5 fish farms. Bars are mean + SE of $16 \times 1$ min counts. (a-c) Altea; $(d-f)$ Campello; $(g-i)$ Guardamar; (j-l) Los Cristianos; (m-o) San Andrés. The percentage given in each panel shows the contribution of that taxon to the overall biomass at the farm 
Table 4. ANOVA comparing abundances and biomasses of the 3 most dominant taxa at the 4 depth strata, 3 sampling times and 2 sites at each of the 5 sea-cage fish farms. Species are ranked in order of their dominance for both abundance and biomass. Values given in the tables are $F$-values. Significant at ${ }^{* *} \mathrm{p}=0.01$. ns: not significant. M: Mugilidae; T. med: Trachurus mediterraneus; O. mel: Oblada melanura; S. sph: Sphyraena sphyraena; T: Trachurus sp.; Chond: chondrichthyid rays; H. lon: Heteroconger longissimus; P. pag: Pagrus pagrus; S. mad: Sardinella maderensis; S. pil: Sardina pilchardus

\begin{tabular}{|c|c|c|c|c|c|c|c|}
\hline \multirow{2}{*}{$\begin{array}{l}\text { a) Altea } \\
\text { Source }\end{array}$} & \multirow[b]{2}{*}{$\mathrm{df}$} & \multicolumn{3}{|c|}{ Abundance } & \multicolumn{3}{|c|}{ Biomass } \\
\hline & & S. aurita & T. ovatus & $M<20$ & S. aurita & $M \geq 20 \mathrm{~cm}$ & T. ovatus \\
\hline Depth & 3 & $13.0^{* *}$ & $3.4 \mathrm{~ns}$ & $408.1^{* *}$ & $11.6^{* *}$ & $14.1^{* *}$ & $2.4 \mathrm{~ns}$ \\
\hline Time & 2 & $2.2 \mathrm{~ns}$ & $5.7 \mathrm{~ns}$ & $0.0 \mathrm{~ns}$ & $1.7 \mathrm{~ns}$ & $4.2 \mathrm{~ns}$ & $1.7 \mathrm{~ns}$ \\
\hline $\mathrm{D} \times \mathrm{T}$ & 6 & $1.1 \mathrm{~ns}$ & $1.7 \mathrm{~ns}$ & $0.0 \mathrm{~ns}$ & $0.9 \mathrm{~ns}$ & $2.5 \mathrm{~ns}$ & $0.6 \mathrm{~ns}$ \\
\hline $\mathrm{S}(\mathrm{D} \times \mathrm{T})$ & 12 & $2.9^{* *}$ & $3.3^{* *}$ & $2.1 \mathrm{~ns}$ & $3.5^{* *}$ & $2.0 \mathrm{~ns}$ & $1.4 \mathrm{~ns}$ \\
\hline Residual & 1688 & & & & & & \\
\hline \multicolumn{8}{|c|}{ b) Campello } \\
\hline Source & df & T. med & $\mathrm{M}<20 \mathrm{~cm}$ & O. mel & T. med & S. sph & O. mel \\
\hline Depth & 3 & $30.5^{* *}$ & $6.4 \mathrm{~ns}$ & $12.8^{* *}$ & $28.2^{* *}$ & $1.4 \mathrm{~ns}$ & $1.6 \mathrm{~ns}$ \\
\hline Time & 2 & $3.3 \mathrm{~ns}$ & $4.5 \mathrm{~ns}$ & $2.3 \mathrm{~ns}$ & $3.1 \mathrm{~ns}$ & $0.9 \mathrm{~ns}$ & $11.7^{* *}$ \\
\hline $\mathrm{D} \times \mathrm{T}$ & 6 & $1.1 \mathrm{~ns}$ & $4.5 \mathrm{~ns}$ & $1.0 \mathrm{~ns}$ & $1.1 \mathrm{~ns}$ & $0.9 \mathrm{~ns}$ & $8.9^{* *}$ \\
\hline $\mathrm{S}(\mathrm{D} \times \mathrm{T})$ & 12 & $2.0 \mathrm{~ns}$ & $0.5 \mathrm{~ns}$ & $0.4 \mathrm{~ns}$ & $2.2 \mathrm{~ns}$ & $1.0 \mathrm{~ns}$ & $0.2 \mathrm{~ns}$ \\
\hline Residual & 168 & & & & & & \\
\hline \multicolumn{8}{|c|}{ c) Guardamar } \\
\hline Source & df & $T<20 \mathrm{~cm}$ & $M \geq 20 \mathrm{~cm}$ & $\mathrm{M}<20 \mathrm{~cm}$ & $M \geq 20 \mathrm{~cm}$ & T. med & $T<20 \mathrm{~cm}$ \\
\hline Depth & 3 & $1.0 \mathrm{~ns}$ & $14.1^{* *}$ & $149.8^{* *}$ & $17.1^{* *}$ & $1.0 \mathrm{~ns}$ & $1.0 \mathrm{~ns}$ \\
\hline Time & 2 & $41.5^{* *}$ & $0.9 \mathrm{~ns}$ & $1.1 \mathrm{~ns}$ & $3.0 \mathrm{~ns}$ & $3.0 \mathrm{~ns}$ & $31.0^{* *}$ \\
\hline $\mathrm{D} \times \mathrm{T}$ & 6 & $14.0^{* *}$ & $9.1^{* *}$ & $0.8 \mathrm{~ns}$ & $6.5^{* *}$ & $2.4 \mathrm{~ns}$ & $10.3^{* *}$ \\
\hline $\mathrm{S}(\mathrm{D} \times \mathrm{T})$ & 12 & $0.5 \mathrm{~ns}$ & $0.8 \mathrm{~ns}$ & $0.2 \mathrm{~ns}$ & $0.8 \mathrm{~ns}$ & $1.3 \mathrm{~ns}$ & $0.6 \mathrm{~ns}$ \\
\hline Residual & 1688 & & & & & & \\
\hline \multicolumn{8}{|c|}{ d) Los Cristianos } \\
\hline Source & $\mathrm{df}$ & B. boops & H. lon & P. pag & B. boops & Chond & H. lon \\
\hline Depth & 3 & $66.1^{* *}$ & $28.2^{* *}$ & $0.87 \mathrm{~ns}$ & $10.8^{* *}$ & $2.9 \mathrm{~ns}$ & $23.2^{* *}$ \\
\hline Time & 2 & $0.1 \mathrm{~ns}$ & $0.3 \mathrm{~ns}$ & $1.1 \mathrm{~ns}$ & $5.6 \mathrm{~ns}$ & $2.5 \mathrm{~ns}$ & $0.4 \mathrm{~ns}$ \\
\hline $\mathrm{D} \times \mathrm{T}$ & 6 & $1.5 \mathrm{~ns}$ & $0.3 \mathrm{~ns}$ & $1.3 \mathrm{~ns}$ & $2.7 \mathrm{~ns}$ & $1.4 \mathrm{~ns}$ & $0.4 \mathrm{~ns}$ \\
\hline $\mathrm{S}(\mathrm{D} \times \mathrm{T})$ & 12 & $3.3^{* *}$ & $7.2^{* *}$ & $5.0^{* *}$ & $5.1^{* *}$ & $1.1 \mathrm{~ns}$ & $6.2 \mathrm{~ns}$ \\
\hline Residual & 1688 & & & & & & \\
\hline \multicolumn{8}{|c|}{ e) San Andrés } \\
\hline Source & $\mathrm{df}$ & B. boops & S. mad & S. pil & B. boops & Chond & H. lon \\
\hline Depth & 3 & $2.0 \mathrm{~ns}$ & 1.1ns & $1.0 \mathrm{~ns}$ & $3.6 \mathrm{~ns}$ & $11.2^{* *}$ & $23.8^{* *}$ \\
\hline Time & 2 & $0.7 \mathrm{~ns}$ & $0.3 \mathrm{~ns}$ & $1.4 \mathrm{~ns}$ & $0.5 \mathrm{~ns}$ & $3.5 \mathrm{~ns}$ & $0.3 \mathrm{~ns}$ \\
\hline $\mathrm{D} \times \mathrm{T}$ & 6 & $3.5 \mathrm{~ns}$ & $0.8 \mathrm{~ns}$ & $0.9 \mathrm{~ns}$ & $2.8 \mathrm{~ns}$ & $3.5 \mathrm{~ns}$ & $0.3 \mathrm{~ns}$ \\
\hline $\mathrm{S}(\mathrm{D} \times \mathrm{T})$ & 12 & $2.4^{* *}$ & $4.0^{* *}$ & $3.7^{* *}$ & $1.8 \mathrm{~ns}$ & $3.0^{* *}$ & $2.9^{* *}$ \\
\hline Residual & 1688 & & & & & & \\
\hline
\end{tabular}

the sparid Boops boops (TL $=6$ to $20 \mathrm{~cm}$, Figs. 4j \& 5j). Their abundances and biomasses were greatest in either the cage or surface strata, depending on the site and sampling time (Table $4 \mathrm{~d}$ ). In contrast, abundances and biomasses of Heteroconger longissimus were always greatest in bottom counts (Figs. 4k \& 5l), although this also varied with site and time. Pagrus pagrus were abundant on the bottom at the second sampling time only (Fig. 41). Despite their relatively low abundance in bottom and midwater counts, the large sizes of Chondrichthyid rays aggregated at Los Cristianos meant that they were the second most important taxa for biomass (Fig. 5k).
Boops boops (TL $=12$ to $24 \mathrm{~cm}$ ) also clearly dominated the assemblage of wild fish at San Andrés (Figs. $4 \mathrm{~m} \& 5 \mathrm{~m}$ ). Their abundances were higher at the bottom than at all other depth strata and sampling time combinations at 2 of the 3 sampling times, although biomass did not vary significantly among depths or sampling times (Table 4e). Sardinella maderensis (Fig. 4n) and Sardina pilchardus (Fig. 4o) were abundant in either the midwater, cage or surface strata at particular sampling times and sites. Chondrichthyid rays only occurred in bottom counts and contributed almost $30 \%$ of the biomass at San Andrés (Fig. 5n), with significantly higher abundances at particular 
sampling times and sites. As at Los Cristianos, biomasses of Heteroconger longissimus were significantly greater in bottom counts than at all other depth strata (Fig. 5o), although this also varied with site and time.

Size frequency distributions at farms by depth strata

Distinct differences in the sizes of associated fish existed among farms, with low overall percentages of large fish > $20 \mathrm{~cm}$ at Guardamar (23\%), Los Christianos $(11 \%)$ and San Andrés (25\%) compared to Altea (95\%) and Campello (81\%). However, large fish $>20 \mathrm{~cm}$ were clearly more common in the cage stratum $(71.4 \%)$ compared to the bottom, midwater and surface strata (16 to $25 \%$ ). Small fish in the 0-9 and/or 10-19 cm size classes were prevalent at all farms at the bottom and surface (Fig. 6). At Altea, fish in the 0-9 and 10-19 cm size classes were located only at the bottom (Serranus hepatus) and the surface (Mugilidae) (Fig. 6a). Larger
Bottom

(a) Altea

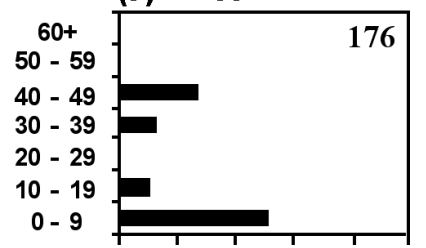

(b) Campello

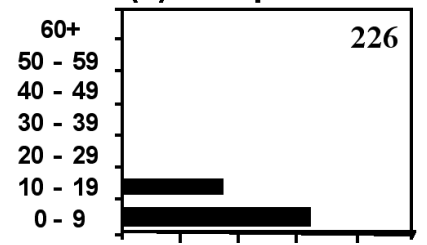

(c) Guardamar

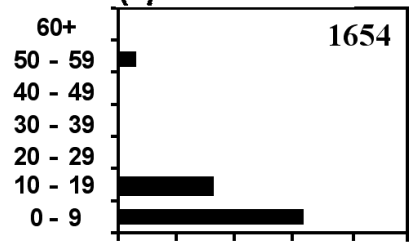

(d) Los Cristianos

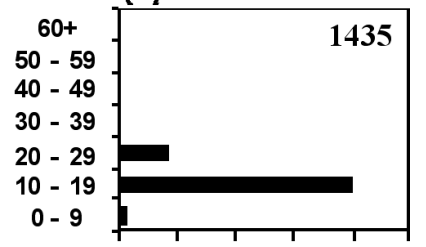

(e) San Andres

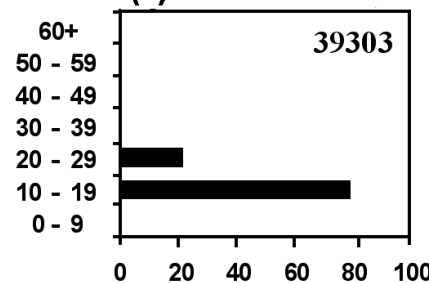

Midwater
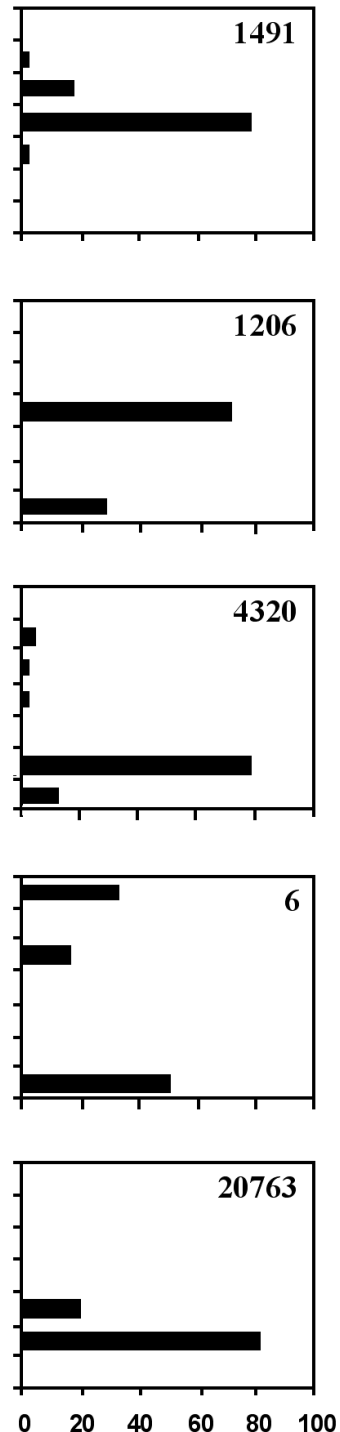

Cage
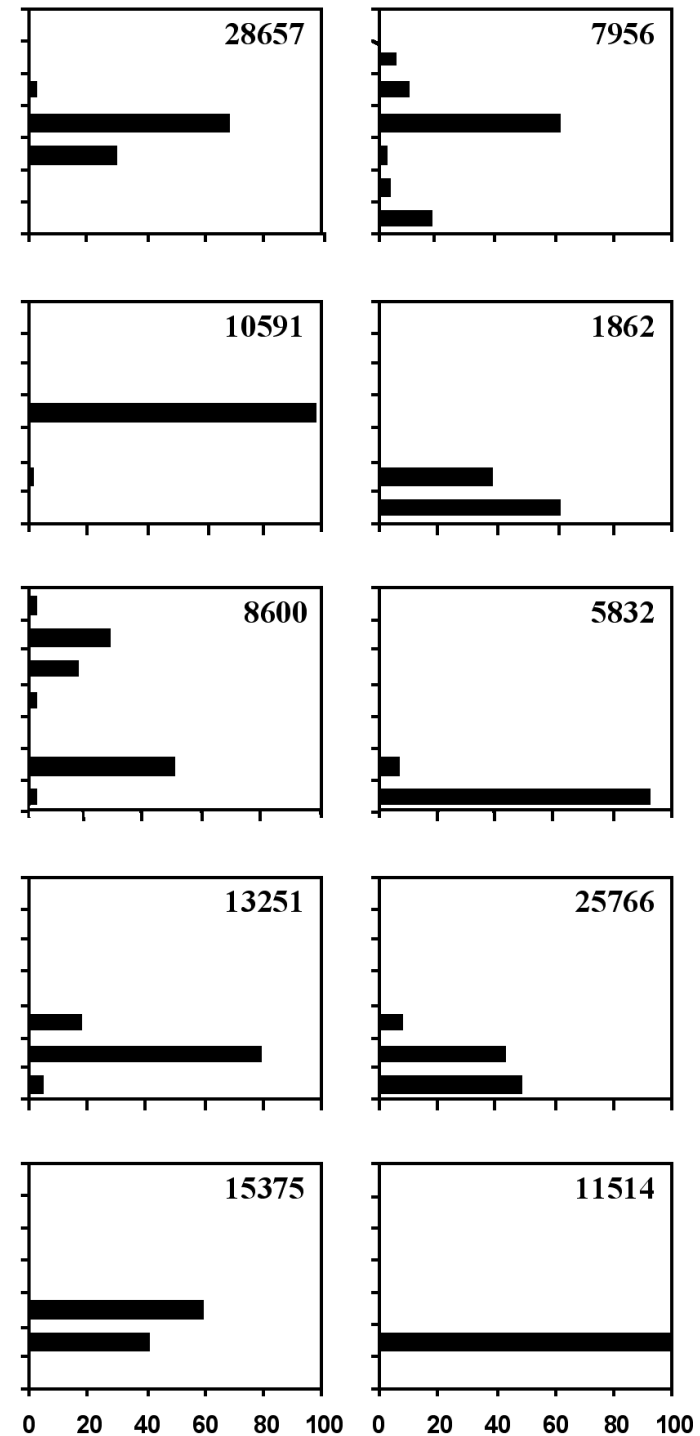

Surface
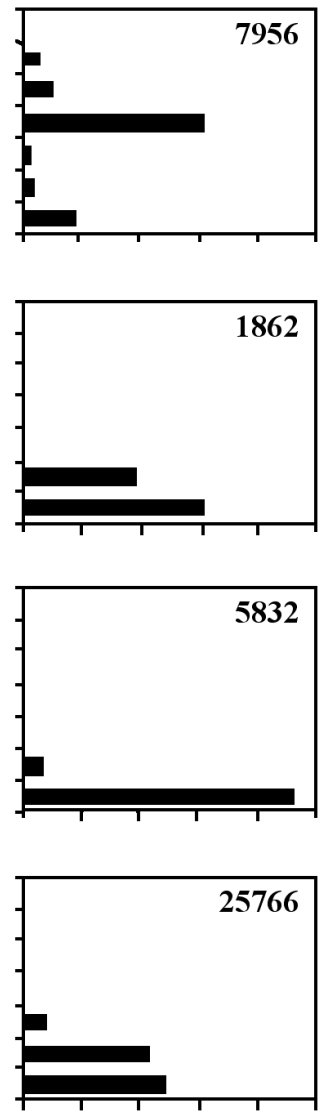

$\%$ of total represented by each size class

Fig. 6. Proportions of fish in total length size classes $(\mathrm{cm})$ in the 4 depth strata (bottom, midwater, cage, surface) at each of the 5 fish farms (Altea, Campello, Guardamar, Los Cristianos, San Andrés). Total number of fish observed in $48 \times 1$ min timed counts in the particular depth stratum at that farm is given at the top right of each panel 
fish of 30-39 cm (Sardinella aurita, Trachinotus ovatus and Mugilidae) dominated assemblages in the midwater and cage strata, and also occurred at the surface. Likewise, fish of 30-39 cm (Trachurus mediterraneus) dominated the midwater and cage strata at Campello, with only fish of $0-19 \mathrm{~cm}$ seen at the bottom $(S$. hepatus, Serranus cabrilla and Coris julis) and the surface (Mugilidae and Oblada melanura) (Fig. 6b). Small fish of 0-19 cm occurred throughout the water column at Guardamar (Trachurus sp., Boops boops and Mugilidae), with the $0-9 \mathrm{~cm}$ class dominant at the bottom ( $B$. boops) and the surface (Mugilidae and Engraulis encrasicolus) (Fig. 6c). A significant proportion of fish observed in the cage stratum were large Mugilids of 40-59 cm. Sizes of fish were more homogeneous among the bottom, cage and surface strata at Los Cristianos where $B$. boops of 10-19 cm dominated, with too few fish observed in the midwater to enable a valid comparison (Fig. 6d). However, small juveniles of 0-9 cm (mainly B. boops) were most prevalent in surface waters. The bottom, midwater and surface strata at San Andrés were dominated by B. boops of 10-19 cm (Fig. 6e). In contrast, the cage stratum was dominated by larger B. boops (20-29 cm).

\section{DISCUSSION}

\section{Wild fish aggregated at fish farms}

Although zoogeographic differences between the Mediterranean and the Canary Islands fish fauna exist, we have found important consistencies in certain responses of the coastal ichthyofauna to the presence of fish farms. Our results show that at all 5 farms sampled, just 1 to 3 taxa (principally Mugilidae, Trachurus mediterraneus, Sardinella aurita or Boops boops) dominated the assemblages of associated wild fish. Similar species have been reported from previous studies in the Mediterranean (Dempster et al. 2002, Smith et al. 2003, Thetmeyer et al. 2003) and the Canary Islands (Boyra et al. 2004, Tuya et al. 2005). A general picture is emerging that planktivorous pelagic species dominate assemblages and that these fish opportunistically feed upon food pellets lost from cages. Fish such as T. mediterraneus, Trachinotus ovatus, S. aurita, B. boops and the large mugilids may have learnt such behaviour through classic conditioning, as has been observed elsewhere where wild fish are fed by humans (e.g. Milazzo et al. in press). Further, the sizes of these species are large and most are likely to be adult (\% adult in the cage stratum: $71 \%$ this study; $85 \%$ Dempster et al. 2002). The high densities of large Chondrichthyid rays that we observed at fish farms in the Canary Islands have also been described previously (Boyra et al. 2004, Tuya et al. 2005). We do not know if these rays fed upon lost feed and dead cultured fish as well as benthic infauna when they foraged on the bottom. Our observations of groups of bottlenose dolphins Tursiops truncatus around both Canary Island farms mirror those of Bearzi et al. (2004) in Greece, who suggested that dolphins may have been feeding on the abundant prey species (wild fish) located next to cages. Future research into the effects of fish farms on wild fish and the role of wild fish in modifying nutrient cycling around farms should clearly focus on these few dominant pelagic and demersal species. Fisheries-related effects of fish farms on wild fish at scales greater than the immediate vicinity of the cages have been demonstrated in Greece (Machias et al. 2005) and warrant further research in coastal areas where farms are wide-spread.

\section{Vertical and horizontal variability of fishes associated within farms}

Remarkable consistency was observed in the patterns of aggregation of wild fish with depth at the 3 Mediterranean farms, even though different species dominated the aggregations at each farm. Opposite patterns of aggregation were observed at the 2 Canary Island farms, with highest abundance and biomass located at the surface at one farm (Los Cristianos) and on the bottom beneath the other (San Andrés). This was despite the fact that both farms were dominated by the planktivorous Boops boops. Mechanisms behind the different vertical patterns of aggregation that we observed are unknown. Such differences in assemblages among farms can be attributable to: (1) differences in the input of organic matter into the system, (2) environmental conditions intrinsic to each farm, or (3) the mosaic of marine habitats that surround each farm and the local distribution of species available to recruit (Dempster et al. 2002, Tuya et al. 2005). Variability in water temperatures and horizontal Secchi distance (an index of turbidity) did not explain the observed differences in assemblage structure among farms. Water temperatures and sampling times varied among the Mediterranean farms, yet the vertical structures of the wild fish assemblages were consistent. In contrast, water temperatures and Secchi readings were almost identical at the 2 Canary farms although vertical fish assemblage structures differed greatly. Differences in farm size and therefore organic input to the environment existed, but at least for the 3 Mediterranean farms this could not explain why such different species dominated assemblages. Location is likely to be a major influence on the presence and abundance 
of some species, and early colonisers may be important in structuring the assemblage (Dempster et al. 2002), as has been commonly found for aggregations of wild fish at artificial reefs (Bohnsack 1989).

The Mediterranean farms were located approximately $3 \mathrm{~km}$ from the coast on sandy sediments and structureless seafloor. The 2 Canary Island farms were also located on sandy sediments but were nearer to the coast ( 0.4 to $1.2 \mathrm{~km}$ ) on steeply shelving bottoms close to open oceanic waters. These location-related differences may have contributed to the greater diversity of demersal fish species observed at the Canary Island farms.

Many of the dominant species varied significantly at the level of sites within farms, indicating that aggregations were spatially heterogeneous throughout the farm complexes, as observed previously by Boyra et al. (2004). We hypothesise that for the large planktivorous fish, this may be a response to where feeding is occurring within the farm complex. Variability at the small spatial scale of 10 s of metres within farms has implications for sampling designs of future studies that seek to estimate the overall biomass of wild fish associated with particular farms.

A separate yet consistent pattern observed was that small juvenile fish were concentrated only on the bottom and at the surface. For the small juveniles (e.g. Mugilidae $<20 \mathrm{~cm}$, Oblada melanura) found at the surface, this may be an inherent behaviour to associate very closely with floating structures, as observed for numerous small species of fish (Castro et al. 2002). However, their distribution may also reflect behavioural avoidance of the large and super-abundant wild fish located immediately below in the cage stratum.

\section{Implications for models of fish farm nutrient dynamics}

While many of the variables concerning the environmental impacts of fish farms can be measured, modelled or predicted from general principles before farms are placed in particular environments, our results clearly show that the biomass of wild fish, and their distribution in the water column, cannot be predicted $a$ priori. We demonstrated here that wild fish assemblage structure differed vertically in different ways among 5 farms. Moreover, Dempster et al. (2002) recorded 5 distinct wild fish assemblage types in the cage stratum at 9 fish farms along a $300 \mathrm{~km}$ section of the Spanish coastline. Due to the unpredictability of wild fish assemblages at farms, modelling the input of nutrients to the environment may best be conducted in a 2-phase process. Phase 1 would involve a traditional approach to modelling nutrient flows for the assess- ment before installation of the farm (e.g. DEPOMOD, Cromey et al. 2002; MERAMOD, Cromey \& White 2004). Phase 2 would involve modifying the initial model once the farm was in place and information on the biomass and depth structure of wild fish was generated.

A range of extra information concerning the activities of wild fish around farms should be incorporated into this second phase of modelling. Consumption of lost food by wild fish in the water column has been often observed (Dempster et al. 2002, Thetmeyer et al. 2003) but never measured in marine environments (although see Philips et al. 1985 and Johansson et al. 1998 for freshwater examples). Experiments to determine the amount of food consumed by different types of assemblages, coupled with stomach content analyses, would produce useful information on the amount of lost food consumed before it reaches the bottom. Leaching of nutrients into the water column from the faeces of wild fish (e.g. Trachurus mediterraneus, Sardinella aurita, Boops boops, Mugilidae and Trachinotus ovatus) and settlement rates of faeces are known to be highly species specific (Fernandez-Jover et al. 2004), and sophisticated modelling should account for this.

Models must also include variability resulting from seasonal changes in the composition of wild fish aggregated around farms, which is considerable at the 3 Mediterranean farms studied (Valle 2005, D. Fernandez-Jover et al. unpubl. data), but may be less pronounced in other areas (e.g. Canary Islands; Boyra et al. 2004). A further step would be to incorporate the movements of wild fish around farms into models; however, there are presently no data to describe this. While general relationships of the activities of wild fish around farms can be derived for use in modelling, our results show that the biomass and depth distribution of aggregated wild fish must be specifically generated for each farm before such parameters can be incorporated into models. Within this context, developing techniques to rapidly and accurately assess the aggregated biomass of large schools of pelagic fish within farm complexes should be a priority for future research (e.g. Thetmeyer et al. 2003). A combination of visual counts for assemblage description and video or echo-integration for overall farm biomass estimation may produce a useful monitoring tool.

Present nutrient dispersal models developed for fish farms in the Mediterranean Sea (MERAMOD, Cromey \& White 2004) specify that sediment re-suspension begins at current speeds $\geq 10 \mathrm{~cm} \mathrm{~s}^{-1}$. We suggest that re-suspension of sediments may occur at lower current speeds or is enhanced at particular farms as a result of bioperturbation due to fish feeding on the bottom. Katz et al. (2002) showed that, when kept in experimental 
enclosures, the bottom feeder Mugil cephalus reduced the impact of sea-cages upon the seafloor by mixing, oxygenating and re-suspending sediments and enhancing effluent dispersal. When wild fish are abundant on the bottom, such as at the 2 Canary Island farms, they may play a large role in re-suspending sediments. In contrast, at the 3 Mediterranean farms, the lack of fish on the bottom beneath cages suggests that little bioperturbation occurs, although we cannot rule out the possibility that some of the abundant species that occurred mainly in the cage and surface strata during morning counts fed on the bottom at other times of the day, as they are known to be benthic feeders elsewhere (e.g. Trachinotus ovatus: da Silva \& Marques 1998; M. cephalus, Liza aurata: Porter et al. 1996, Blanco et al. 2003).

At farms where large chondrichthyid rays are abundant on the bottom, such as San Andrés in the Canary Islands ( 7 species of rays of 30 to $300 \mathrm{~cm}$ body width), biological perturbation of the sediment by these animals is likely to be significant. Chondrichthyid rays disturb bottom sediments when feeding and are important demersal predators and scavengers in many coastal environments; as they increase in size and become more powerful they are able to burrow deeper to catch prey and disturb more sediment (Myliobatis: Gray et al. 1997; Dasyatis: Ebert \& Cowley 2003). Increased abundance of the ray Raja clavata has been associated with increased discards from Greenland shrimp fisheries (Goñi 1998); the profusion of rays beneath fish farms may be similarly related to the abundance of dead cultured fish on the bottom. The role of rays in re-suspending sediments underneath fish farms has never been considered. Further research using exclusion cages and a range of benthic response variables (e.g. Katz et al. 2002) is necessary to determine their role in resuspension and nutrient dispersal around farms. The Canary Islands would be an ideal location to test such hypotheses as chondrichthyid rays are abundant at several farms located there (Boyra et al. 2002, Tuya et al. 2005).

\section{Reducing the benthic impacts of fish farms}

Goldberg \& Naylor (2005) state that establishing viable, long-term solutions to problems in marine aquaculture requires the incorporation of ecological perspectives into management policies. Wild fish have been largely overlooked in management scenarios of the environmental impacts of fish farms (e.g. Read \& Fernandes 2003), partly because good information on their interactions with farms has only been available since 2002 (Dempster et al. 2002, Skog et al. 2003, Boyra et al. 2004, Vita et al. 2004, Felsing et al. 2005, Tuya et al. 2005).
Dempster et al. (2002) suggested that farms along the coast of Spain may act as small accidental Marine Protected Areas (MPAs) because they attracted large multi-species aggregations of adult pelagic fish.

The results of this study, when considered with recent estimates that wild fish greatly reduce sedimenting nutrients beneath coastal sea-cage farms (80\%, Vita et al. 2004; 40 to $60 \%$, Felsing et al. 2005), indicate that protecting the dominant planktivorous species from fishing may be particularly important for reducing impacts upon the benthos. Removal of such species from the surrounds of farms will reduce the amount of waste feed and faeces consumed, thereby increasing the amount of nutrients that settle. Many of the abundant wild fish species around farms are commercially important to local fisheries (e.g. Trachurus mediterraneus, Sardinella aurita, mugilids, Sardina pilchardus, Seriola spp., Spondyliosoma cantharus, Pagrus spp. and Pagellus spp.). However, at least along the Spanish Mediterranean coast, communities of wild fish at fish farms are known to alternate between distinctly different winter/spring and summer/ autumn assemblages (Valle 2005, D. Fernandez-Jover et al. unpubl. data), so it cannot be argued that these fish will be inaccessible to the local fishery on a permanent basis due to their association with farms. While farms in parts of Spain receive some protection from fishing, farming locations in, e.g., Greece, Italy and the Canary Islands have no such protection in place. We therefore suggest that specific management measures be enacted to prohibit fishing around farms where wild fish aggregate in great numbers, so that the positive effect they have on reducing benthic impact may be fully harnessed.

Very few demersal fish were observed at the 3 Mediterranean fish farms compared to the 2 farms in the Canary Islands. Angel et al. (2002) recorded numerous species and considerable abundances of wild fish aggregated at artificial reefs placed underneath fish farms off the coast of Israel. Such a strategy may be particularly appropriate at farms where few demersal fish species occur naturally, such as at the 3 Mediterranean farms investigated here, to attract larger numbers of wild demersal fish to consume lost feed that reaches the bottom at times when few pelagic fish are present.

Very little information exists on the patterns of aggregation and movement of dominant wild fish in the vicinity of farms on a $24 \mathrm{~h}$ time scale, as visual census techniques (whether observer- or video-based) are limited to daylight hours and locations and times of adequate visibility. Acoustic survey techniques are not limited to this extent. They have not yet been used around fish farms, but may provide useful information on the movements of whole schools of fish in the vicin- 
ity of farms. They have been applied to describe fish communities around other mariculture structures (e.g. mussel longlines, Brehmer et al. 2003), which indicates that the technique has potential. Ultra-sonic tags and active or passive tracking of individual fish to describe horizontal and vertical movements over scales of $100 \mathrm{~s}$ to 1000 s of metres and for weeks to months will also provide novel information (Cooke et al. 2004). For instance, $24 \mathrm{~h}$ depth profiles, foraging patterns and residence periods could be generated for the dominant planktivorous species and large chondrichthyid rays.

Although rapid expansion of sea-cage fish farming is occurring along temperate and tropical coastlines, there remains a significant 'information vacuum' on the types, abundances and biomasses of wild fish that occur at such coastal installations. Dempster et al. (2002) highlighted the need for more extensive research on the interactions of wild fish at fish farms throughout the Mediterranean Sea. Scattered empirical evidence (Bjordal \& Skar 1992, Johansson et al. 1998, Skog et al. 2003) and a mass of anecdotal information suggests that the phenomenon of aggregation of wild fish is not restricted to warm-water areas, and may also be important in higher latitude locations such as northern Europe, north America, southern Australia and Chile where sea-cage aquaculture is particularly extensive. No studies have directly investigated these locations to date. To establish a complete picture of how nutrients are dispersed or assimilated in all coastal systems where sea-cage culture prevails, the role that wild fish play must be fully assessed and integrated into models.

Acknowledgements. We are grateful to Basademar, Cudomar, Martorres, Aceac and Cedras, and all of the fish farm workers who gave us access, provided boat time for the study and generally assisted wherever possible. We thank A. del Rosario Pinilla and N. Rodríguez Sánchez for assistance during sampling. H. Gibb (Swedish Agricultural University) improved an earlier version of the manuscript. The study forms part of the ACUFISH project (Marine Science Department, University of Alicante) and was funded by Spanish Ministry of Science grant MYCT-REN2003-00794. Financial support in the Canary Islands was provided by the 'Canarias, por una Costa Viva' framework (Ministerio de Medio Ambiente). Travel to Spain for T.D. was funded by the University of Alicante.

\section{LITERATURE CITED}

Angel DL, Eden N, Breitsen S, Yurman A, Katz T, Spanier T (2002) In situ biofiltration: a means to limit the dispersal of effluents from marine finfish cage aquaculture. Hydrobiologia 469:1-10

Bayle JT, Valle C, Verdú A (2002) EcoCEN: application for managing fish visual counts. Informes y estudios COPEMED No. 7: ECOCEN. Available at www.faocopemed.org

Bearzi G, Quondam F, Politi E (2004) Bottlenose dolphins for- aging alongside fish farm cages in the eastern Ionian Sea coastal waters. Eur Res Cetacean 15:292-293

Bjordal Å, Skar AB (1992) Tagging of saithe (Pollachius virens) at a Norwegian fish farm: preliminary results on migration. ICES Counc Meet Pap 1992/G:35

Black KD (ed) (2001) Environmental impacts of aquaculture. Academic Press, Sheffield

Blanco S, Romo S, Villena MJ, Martínez S (2003) Fish communities and food web interactions in some shallow Mediterranean lakes. Hydrobiologia 506:473-480

Bohnsack J (1989) Are high densities of fishes at artificial reefs the results of habitat limitation or behavioural preference? Bull Mar Sci 44:631-645

Boyra A, Sanchez-Jerez P, Tuya F, Espino F, Haroun R (2004) Attraction of wild coastal fishes to Atlantic subtropical cage fish farms, Gran Canaria, Canary Islands. Environ Biol Fish 70:393-401

Brehmer P, Gerlotto F, Guillard J, Sanguinède F, Guénnegan Y, Buestel D (2003) New applications of hydroacoustic methods for monitoring shallow water aquatic ecosystems: the case of mussel culture grounds. Aquat Living Resour 16:333-338

Castro JJ, Santiago JA, Santana-Ortega AT (2002) A general theory on fish aggregation to floating objects: an alternative to the meeting point hypothesis. Rev Fish Biol Fish 11: 255-277

Clarke KR (1993) Non-parametric multivariate analyses of changes in community structure. Aust J Ecol 18:117-143

Clarke KR, Green RH (1988) Statistical design and analysis for a 'biological effects' study. Mar Ecol Prog Ser 46:213-226

Clarke KR, Warwick RM (1994) Change in marine communities: an approach to statistical analysis and interpretation. Natural Environmental Research Council, Plymouth

Cooke SJ, Hinch SG, Wikelski M, Andrews RD, Kuchel LJ, Wolcott TG, Butler PJ (2004) Biotelemetry-a mechanistic approach to ecology. Trends Ecol Evol 19:334-343

Cromey C, White P (2004) Development of monitoring guidelines and modeling tools for environmental effects from Mediterranean aquaculture. Meramed Newsletter 4: Potential farm management practice for the reduction of aquaculture impact. Available at www.meramed.com

Cromey CJ, Nickell TD, Black KD (2002) DEPOMOD-modeling the deposition and biological effects of waste solids from marine cage farms. Aquaculture 214:211-239

da Silva M, Marques V (1998) Peixes de Cabo Verde. Ministério do Mar, Gabinete do Secretário de Estado da Cultura. M2-Artes Gráficas, Lisbon

Dempster T, Taquet M (2004) Fish aggregation device research: gaps in current knowledge and future directions for ecological studies. Rev Fish Biol Fish 14:21-42

Dempster T, Sanchez-Jerez P, Bayle-Sempere JT, GiménezCasalduero F, Valle C (2002) Attraction of wild fish to seacage fish farms in the south-western Mediterranean Sea: spatial and short-term temporal variability. Mar Ecol Prog Ser 242:237-252

Dempster T, Sanchez-Jerez P, Bayle-Sempere J, Kingsford M (2004) Extensive aggregations of wild fish at coastal seacage fish farms. Hydrobiologia 525:245-248

Ebert DA, Cowley PD (2003) Diet, feeding behaviour and habitat utilisation of the blue stingray Dasyatis chrysonata (Smith, 1828) in South African waters. Mar Freshw Res 54:957-965

FAO (Food and Agriculture Organisation) (2003) Fishstat Plus. Aquaculture production: quantities 1950-2002. FAO, Rome; also available at www.fao.org/fi/statist/FISOFT/ FISHPLUS.asp

Felsing M, Glencross B, Telfer T (2005) Preliminary study on 
the effects of exclusion of wild fauna from aquaculture cages in a shallow marine environment. Aquaculture 243: 159-174

Feng YY, Li CH, Ping NX, Ling TD, Kyo CI (2004) Development of mariculture and its impacts in Chinese coastal waters. Rev Fish Biol Fish 14:1-10

Fernandez-Jover D, Carratala A, Leon Leon VM, SanchezJerez P, Bayle-Sempere J, Dempster T (2004) Influence of wild fish on the nitrogen cycle around Mediterranean fish farms: leaching from faeces. Abstract, Workshop on the environmental effects of fish farms in the Mediterranean Sea. Barcelona, October 2004. Available at www.medveg. $\mathrm{dk}$

Froese R, Pauly D (2000) FishBase 2000: concepts, design and data sources. ICLARM, Los Baños, Laguna, also available at www.fishbase.org

Goldberg R, Naylor R (2005) Future seascapes, fishing and fish farming. Front Ecol Environ 3:21-28

Goñi R (1998) Ecosystem effects of marine fisheries: an overview. Ocean Coast Manage 40:37-64

Gray AE, Mulligan TJ, Hannah RW (1997) Food habits, occurrence, and population structure of the bat ray, Myliobatis californica, in Humboldt Bay, California. Environ Biol Fish 49:227-238

Håkanson L, Carlsson L, Johansson T (1998) A new approach to calculate the phosphorus load to lakes from fish farm emissions. Aquac Eng 17:149-166

Harmelin-Vivien ML, Harmelin-Vivien JG, Chauvet C, Duval C and 7 others (1985) Evaluation visuelle des peuplements et populations de poissons: méthodes et problèmes. Rev Ecol (Terre Vie) 40:467-539

Hawkins JE, Roberts CM (2004) Effects of artisanal fishing on Caribbean coral reefs. Conserv Biol 18: 215-226

Johansson T, Håkanson L, Borum K, Persson J (1998) Direct flows of phosphorus and suspended matter from a fish farm to wild fish in Lake Southern Bullaren, Sweden. Aquac Eng 17:111-137

Karakassis I, Tsapakis M, Hatziyanni E, Papadopoulou KN, Plaiti W (2000) Impact of cage farming of fish on the seabed in three Mediterranean coastal areas. ICES J Mar Sci 57:1462-1471

Katz T, Herut B, Genin A, Angel DL (2002) Grey mullets ameliorate organically enriched sediments below a fish farm in the oligotrophic Gulf of Aqaba (Red Sea). Mar Ecol Prog Ser 234:205-214

Kingsford M, Battershill C (1998) Studying marine temperate environments: a handbook for ecologists. Canterbury University Press, Christchurch

Machias A, Karakassis I, Giannoulaki M, Papadopoulou KN, Smith CJ, Somarakis S (2005) Response of demersal fish communities to the presence of fish farms. Mar Ecol Prog Ser 288:241-250

Editorial responsibility: Otto Kinne (Editor-in-Chief), Oldendorf/Luhe, Germany
Milazzo M, Anastasi I, Willis TJ (in press) Recreational fish feeding affects coastal fish behavior and increases predation frequency. Mar Ecol Prog Ser

Miller MW, Gerstner CL (2002) Reefs of an uninhabited Caribbean island: fishes, benthic habitat, and opportunities to discern reef fishery impact. Biol Conserv 106:37-44

Philips MJ, Beveridge MCM, Ross LG (1985) The environmental impact of salmonid cage culture on inland fisheries: present status and future trends. J Fish Biol 27: $123-127$

Porter CB, Krost P, Gordin H, Angel DH (1996) Preliminary assessment of grey mullet (Mugil cephalus) as a forager of organically enriched sediments below marine fish farms. Israeli J Aquac 48:47-55

Read P, Fernandes T (2003) Management of environmental impacts of marine aquaculture in Europe. Aquaculture 226:139-163

Sanchez-Mata A, Mora J (2000) A review of marine aquaculture in Spain: production, regulations and environmental monitoring. J Appl Ichthyol 16:209-213

Skog TE, Hylland K, Torstensen BE, Berntssen MHG (2003) Salmon farming affects the fatty acid composition and taste of wild saithe Pollachius virens L. Aquac Res 34: 999-1007

Smith C, Machias A, Giannoulaki M, Somarakis S, Papadopoulou KN, Karakassis I (2003) Diversity study of wild fish fauna aggregating around fish farm cages by means of remotely operated vehicle (ROV). Proceedings of the 7th Hellenic Symposium on Oceanography and Fisheries, Hersonissos, 6-9 May, 2003, book of abstracts, p 227

Theodorou J (1999) Greece focuses on marketing seabass and seabream. Seafood Int 14:35-36

Thetmeyer H, Pavlidis A, Cromey C (2003) Development of monitoring guidelines and modeling tools for environmental effects from Mediterranean aquaculture. Newsletter 3: Interactions between wild and farmed fish. Available at www.meramed.com

Tuya F, Boyra A, Sanchez-Jerez P, Haroun R (2005) Multivariate analysis of the bentho-demersal ichthyofauna along soft bottoms of the Eastern Atlantic: comparison between unvegetated substrates, seagrass meadows and sandy bottoms beneath sea-cage fish farms. Mar Biol 147:1229-1237

Underwood AJ (1997) Experiments in ecology. Their logical design and interpretation. Cambridge University Press, Cambridge

Valle C (2005) Impactos antrópicos sobre la ictiofauna litoral. $\mathrm{PhD}$ thesis, University of Alicante

Vita R, Marín A, Madrid JA, Jiménez-Brinquis B, Cesar A, Marín-Guirao L (2004) Effects of wild fishes on waste exportation from a Mediterranean fish farm. Mar Ecol Prog Ser 277:253-261

Submitted: May 19, 2005; Accepted: July 17, 2005

Proofs received from author(s): November 21, 2005 